\title{
Bone metastases and hypercalcaemia from cutaneous squamous cell carcinoma
}

\author{
Panagiotis J Vlachostergios, ${ }^{1}$ Rajeev L Balmiki ${ }^{2}$
}

${ }^{1}$ Department of Internal Medicine, Lutheran Medical Center, Brooklyn, New York, USA

2Department of Hematology/ Oncology, Lutheran Medical Center, Brooklyn, New York, USA

\section{Correspondence to}

Dr Panagiotis J Vlachostergios, pvlachostergios@lmcmc.com

Accepted 18 April 2014
CrossMark

To cite: Vlachostergios PJ Balmiki RL. BMJ Case Rep Published online: [please include Day Month Year] doi:10.1136/bcr-2014204947

\section{DESCRIPTION}

An 83-year-old man presented with hypercalcaemia $(12.5 \mathrm{mg} / \mathrm{dL}$, reference range $8-10.7 \mathrm{mg} / \mathrm{dL})$ and acute renal failure. On physical examination, the patient was found to have a solid mass behind his left ear (figure 1A). Histopathological examination disclosed squamous cell carcinoma with areas of necrosis. Serum phosphorus level was low $(2 \mathrm{mg} /$ $\mathrm{dL}$, reference range $2.7-4.5 \mathrm{mg} / \mathrm{dL}$ ) and intact parathyroid hormone (iPTH) was also low $(4.4 \mathrm{pg} / \mathrm{mL}$, reference range $10-65 \mathrm{pg} / \mathrm{mL}$ ), whereas an elevated PTH-related peptide (PTH-rP) level was found $(27 \mathrm{pg} / \mathrm{mL}$, reference range $14-25 \mathrm{pg} / \mathrm{mL})$. Bone scan disclosed focal uptake in bilateral parietal skull highly suspicious of bone metastases (figure 1B), further assessed with brain MRI (figure 2). Acute renal failure and hypercalcaemia improved with intravenous fluids without need for bisphosphonate administration. No evidence of other primary solid malignancy was found on CT of the chest and abdomen/pelvis. Workup for multiple myeloma was negative. The patient's tumour was deemed inoperable, and not amenable to systemic chemotherapy due to poor performance status; therefore, palliative radiotherapy was initiated.

\section{Learning points}

- Distant osseous metastases from cutaneous squamous cell carcinoma are rare and the underlying humoral mechanism involves parathyroid hormone-related peptide overproduction by the tumour. Intriguingly, low but detectable serum intact parathyroid hormone levels are also involved in the development of humoral hypercalcaemia of malignancy. ${ }^{2}$

- The incidence of metastases increases with lesions $>2 \mathrm{~cm}$ in width or $4 \mathrm{~mm}$ in depth. In such cases, surgical treatment is limited and the usual approach involves radiotherapy or/ and platinum-based chemotherapy. ${ }^{3}$ 

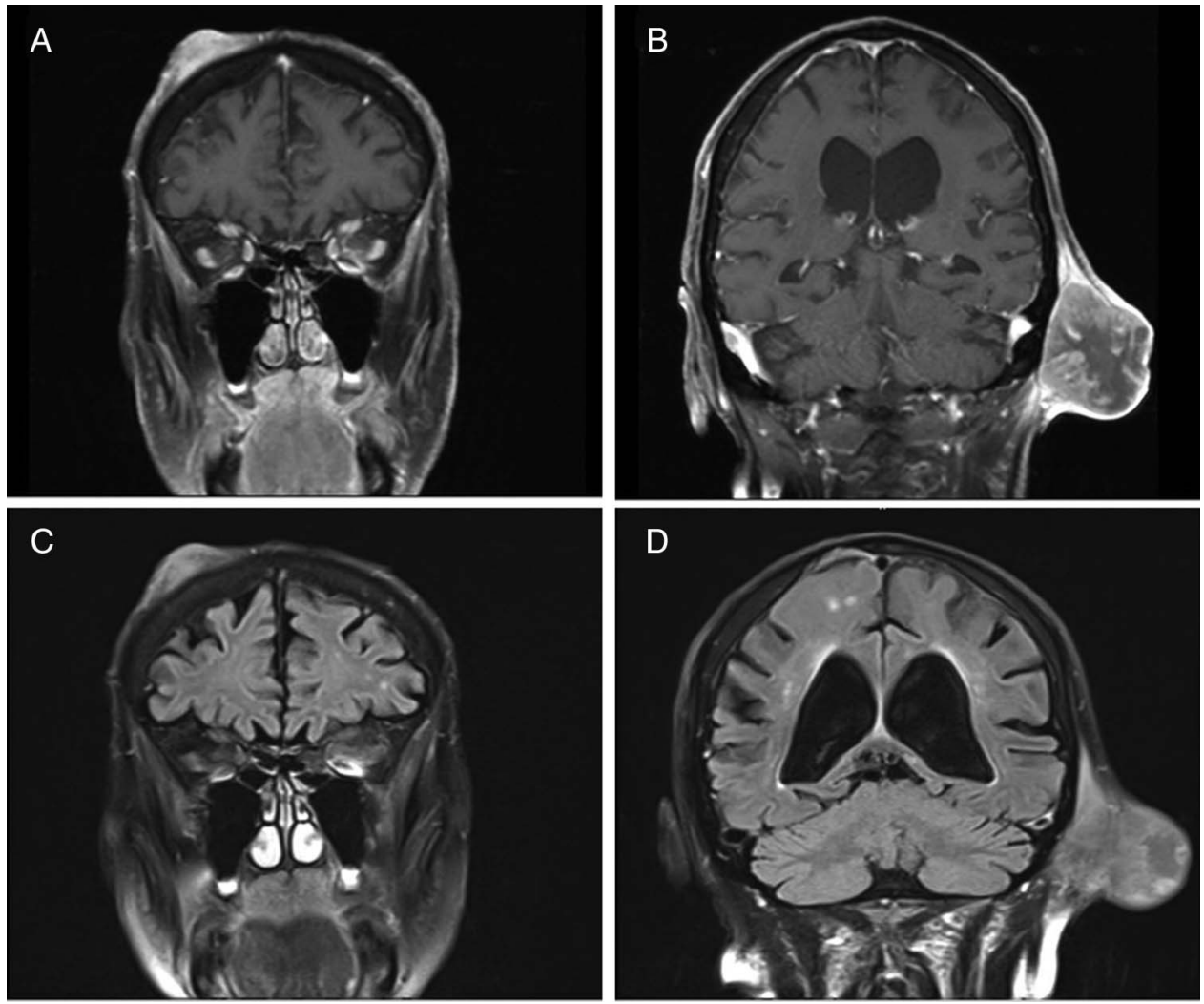

Figure $2 \mathrm{MRI}$ of the brain showing $\mathrm{T1}(\mathrm{A}$ and $\mathrm{B})$ and T2 fluid attenuation inversion recovery $(C$ and $D)$ images of bone thickening and enhancement with indistinct borders, at metastatic ( $A$ and $C)$ and primary site (B and $D)$.

Contributors PJV was involved in conception and design; analysis and interpretation; drafting the manuscript for important intellectual content. PJV and RLB were involved in patient treatment. RLB was involved in manuscript revision.

\section{Competing interests None.}

Patient consent Obtained.

Provenance and peer review Not commissioned; externally peer reviewed.

\section{REFERENCES}

1 Nicolae I, Schipor S. PTH-independent hypercalcaemia and non-melanoma skin cancer. J Eur Acad Dermatol Venereol 2010;24:449-52.

2 Sriussadaporn S, Phoojaroenchanachai M, Ploybutr S, et al. Hypercalcemia of malignancy: a study of clinical features and relationships among circulating levels of calcium, parathyroid hormone and parathyroid hormone-related peptide. J Med Assoc Thai 2007;90:663-71.

3 Kaur MR, Marsden JR, Nelson HM. Humoral hypercalcaemia of malignancy associated with primary cutaneous squamous cell carcinoma. Clin Exp Dermatol 2007;32:237-8.

Copyright 2014 BMJ Publishing Group. All rights reserved. For permission to reuse any of this content visit

http://group.bmj.com/group/rights-licensing/permissions.

BMJ Case Report Fellows may re-use this article for personal use and teaching without any further permission.

Become a Fellow of BMJ Case Reports today and you can:

- Submit as many cases as you like

- Enjoy fast sympathetic peer review and rapid publication of accepted articles

- Access all the published articles

- Re-use any of the published material for personal use and teaching without further permission

For information on Institutional Fellowships contact consortiasales@bmjgroup.com

Visit casereports.bmj.com for more articles like this and to become a Fellow 